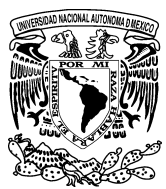

\title{
Determinants of corporate risk disclosure in large Spanish companies: a snapshot
}

\section{Determinantes de la divulgación de riesgos corporativos en empresas españolas grandes: una aproximación}

\author{
Mónica Hernández Madrigal ${ }^{\mathrm{a}, *}$, Beatriz Aibar Guzmán ${ }^{\mathrm{b}}$, \\ Cristina Aibar Guzmán ${ }^{\text {b }}$ \\ ${ }^{a}$ Facultad de Contaduría y Administración, Universidad Autónoma de San Luis Potosí, México \\ ${ }^{\mathrm{b}}$ Facultad de Ciencias Económicas y Empresariales, Universidad de Santiago de Compsotela, España
}

Received 19 November 2014; accepted 8 May 2015

Available online 21 August 2015

\begin{abstract}
Improvements in risk disclosure have been an important part of the corporate governance reforms. This paper is intended to identify the factors that explain the extent to which a sample of 35 listed Spanish firms disclose risk-related information. This study focuses on the risk disclosures made in the corporate governance reports during the year 2009. Using the content analysis technique an index was developed in order to assess the amount and quality of the risk information disclosed by Spanish companies. Several characteristics were selected and their influence on the level of risk disclosure was tested empirically. Results indicate that sector and risk level are positively related to the extent of corporate risk disclosures. This study adds to the international research on risk disclosure by extending the scope of the current understanding of risk reporting practices and their determinants. The findings could be especially useful for regulators and policy-makers in order to enhance risk disclosure and to improve transparency.

All Rights Reserved (C) 2015 Universidad Nacional Autónoma de México, Facultad de Contaduría y Administración. This is an open access item distributed under the Creative Commons CC License BY-NC-ND 4.0.
\end{abstract}

Keywords: Corporate governance; Risk reporting; Content analysis; Stakeholders

\footnotetext{
* Corresponding author.

E-mail address: hmadrigalmonica@uaslp.mx (M. Hernández Madrigal).
} 


\section{Resumen}

Las mejoras en la divulgación de información sobre riesgos constituyen una parte importante de las reformas sobre gobierno corporativo. El objetivo de este artículo es identificar los factores que explican el grado en el que 35 empresas españolas que cotizan en Bolsa divulgan información relacionada con los riesgos. El estudio considera la divulgación sobre riesgos que las empresas hacen por medio de los informes de gobierno corporativo del año 2009. Utilizando la técnica del análisis de contenido, se desarrolló un índice con el fin de evaluar la cantidad y la calidad de la información sobre riesgos divulgada por las empresas españolas. Distintas características fueron seleccionadas y su influencia en el nivel de divulgación sobre riesgos fue probada empíricamente. Los resultados indican que el sector y el nivel de riesgo están positivamente relacionados con el grado de divulgación corporativa sobre riesgos. Este estudio contribuye a la investigación internacional sobre riesgos al extender el entendimiento sobre las prácticas de divulgación sobre riesgos y sus determinantes. Los resultados pueden ayudar a los reguladores y a los emisores de normas con el objeto de fomentar la divulgación sobre riesgos y mejorar la transparencia.

Derechos Reservados ( ) 2015 Universidad Nacional Autónoma de México, Facultad de Contaduría y Administración. Este es un artículo de acceso abierto distribuido bajo los términos de la Licencia Creative Commons CC BY-NC-ND 4.0.

Palabras clave: Gobierno corporativo; Divulgación sobre riesgos; Análisis de contenido; Stakeholders

\section{Introduction}

The financial scandals that have occurred in recent decades have generated a certain level of mistrust towards companies by stakeholders. As a result, stakeholders' demands for more and better corporate information have increased (Boesso \& Kumar, 2007). Interest in corporate information has increased not only among traditional users, but it has also spread to new users who demand clear, relevant and timely information related to both their financial performance and also to other facets of their activity, especially those related to their social dimension and corporate risks.

Improvements in risk disclosure play an important role in protecting stakeholders' interests and, accordingly, they are an important part of the corporate governance reforms (Solomon, Solomon, Norton, \& Joseph, 2000). At the same time, in order to generate trust and gain social legitimacy, firms have responded to the increasing stakeholders' pressures by voluntarily disclosing a greater amount of risk-related information (Abraham \& Cox, 2007). The aim of this paper is to identify the determinants of corporate risk disclosure by adopting the theoretical postulates of the stakeholder theory as explanatory arguments of the influence of such factors.

The rest of the paper is organized as follows: following the literature review, the construction of the hypotheses on the impact of several factors on the level of risk information disclosed by Spanish companies is presented. The research design is exposes in the third section Results are presented and discussed in the fourth section. The final section summarizes the main conclusions of the study with a brief discussion on its implications for future research.

\section{Background and hypotheses}

\section{Previous studies related to risk disclosure}

Corporate risk disclosures may be part of an organizational strategy in order to manage public expectations and to justify corporate risk management (Power, 2007; Gabillon \& Gabillon, 2012). 
According to the most recent study carried out by the Institute of Chartered Accountants in England and Wales (ICAEW, 2011), it is important that companies disclose information related to their experience of risk as well as the lessons that they have learnt over time. In the absence of specific regulations, managers decide both the type and the amount of risk information to be disclosed (Beretta \& Bozzolan, 2004). Therefore, it is necessary to analyze the reasons why companies decide to voluntarily disclose corporate risk information.

Several theories have been used to analyze the drivers of corporate disclosures. This study considers the stakeholder theory postulates in explaining companies' motivations to disclose risk information. According to this theory, companies made voluntary disclosures as part of their efforts to manage their stakeholders' perceptions (Boesso \& Kumar, 2007) and, at the same time, the different stakeholders need to consider the part that they play in the improvement of corporate disclosure (Abraham \& Shrives, 2014).

From the stakeholder theory standpoint, interest in corporate information is not limited to just shareholders and other investors, but spreads to other stakeholder groups. Depending on the extent to which firms recognize the legitimacy of such stakeholders' interests, they tend to report more voluntary information in order to meet their requests. This theory focuses its attention on an organization's most influential stakeholders, namely those who can, directly or indirectly, influence it. According to Boesso and Kumar (2007), the more critical a stakeholder group is considered to be to a company, the greater its influence on the company's disclosure practices.

Miihkinen (2012, p. 442) defines risk disclosure as "all information that firms provide in the risk reviews they present in their annual reports". The study of risk disclosure can be considered a new area of research in financial accounting (Linsley \& Shrives, 2006). In this respect, up until the end of the nineties little attempt was made by the academic community to outline the improvements in risk disclosure or test these empirically (Solomon et al., 2000). In fact, as stated by Woods, Dowd \& Humphrey et al. (2008, p. 14), "much of the work on risk disclosures in the 1990s centred on debates and discussions regarding desired, rather than actual, forms of disclosure". However, as a result of the increased attention paid by regulatory bodies to the risk information disclosed by companies as well as the increase experienced in corporate risk disclosure, there has in recent years been a growing interest among researchers in this area and, as a result, an increase in this type of research. Hence in the past few years it has been possible to find empirical evidence related to risk disclosure (Jorgensen \& Kirschenheiter, 2003; Woods \& Reber, 2003; Beretta \& Bozzolan, 2004; Botosan, 2004; Dunne et al., 2004; Linsley \& Shrives, 2006; Linsley, Shrives, \& Crumpton, 2006; Dobler, 2008; Cabedo Semper \& Tirado Beltrán, 2009; Ali \& Taylor, 2014; Rodríguez Domínguez \& Noguera Gámez, 2014).

These studies focus on different aspects of risk disclosure, among others: the advantage of risk disclosures for the investors (Rajgopal, 1999; Hodder, Koonce, \& McAnally, 2001; Linsley \& Shrives, 2006); the potential benefits arising from risk disclosure for the companies (Linsley \& Shrives, 2000); the characteristics of risk disclosures (Linsley \& Shrives, 2000; Linsley \& Shrives, 2006); Beretta \& Bozzolan, 2004 the relationship between the extent to which the companies disclose information and certain company characteristics (such as the size of the company [Beretta \& Bozzolan, 2004; Lajili \& Zéghal, 2005; Mohobbot, 2005; Linsley \& Shrives, 2006; Cabedo Semper \& Tirado Beltrán, 2009], the type of industry [Beretta \& Bozzolan, 2004; Abraham \& Cox, 2007]; the risk level of the company [Ahmed \& Courtis, 1999; Linsley \& Shrives, 2006; Cabedo Semper \& Tirado Beltrán, 2009], the structure of the Board of Directors [Abraham \& Cox, 2007; Cabedo Semper \& Tirado Beltrán, 2009; Rodríguez Domínguez \& Noguera Gámez, 2014]) and the effect of the existence of obligatory requirements related to risk disclosure (Rajgopal, 1999; Woods \& Reber, 2003; Dunne et al., 2004; Rodríguez Domínguez \& Noguera Gámez, 2014). 
Likewise, other studies compare the pattern of risk information between different countries (Woods \& Reber, 2003; Lajili \& Zéghal, 2005; Dobler, Lajili, \& Zéghal, 2011; Ali \& Taylor, 2014). Even though the majority of these studies focus on the disclosure of financial risks (Blankley, Lamb, \& Schroeder, 2002; Ahmed, Beatty, \& Bettinghaus, 2004), in recent years new empirical evidence has emerged relating to all kinds of risk, including strategic and operative, as well as financial (Beretta \& Bozzolan, 2004; Linsley \& Shrives, 2006). However, as Beretta and Bozzolan (2004) indicate, empirical research in this area is still limited and offers only tentative and preliminary conclusions.

To the best of our knowledge, there is little empirical evidence in Spain concerning disclosure of risk-related information (Cabedo Semper \& Tirado Beltrán, 2009; Rodríguez Domínguez \& Noguera Gámez, 2014), hence it can be concluded that knowledge of the practices developed by Spanish companies in relation to the disclosure of risk-related information is quite poor. Therefore, although there is empirical evidence relating to company practices for the disclosure of social information by Spanish companies (Ochoa-Laburu \& Aranguren-Gómez, 2005; Gallego-Álvarez, 2006; Callao-Gastón, Gasca-Galán, \& Jarne-Jarne, 2007; Aranguren-Gómez \& Ochoa-Laburu, 2008; García-Sánchez, 2008; Prado-Lorenzo, Gallego-Álvarez, \& García-Sánchez, 2009), the majority of the studies have focused on the analysis of disclosures related to aspects of corporate governance other than internal control and risk reporting, such as the structure of the Board, the ownership structure of the characteristics of the Audit Committees, as well as environmental information (Moneva \& LLena, 2000; Larrinaga, Carrasco, Correa, Llena, \& Moneva, 2002; Archel Domench, 2003; García-Ayuso \& Larrinaga, 2003; Criado-Jiménez, Fernández-Chulián, Husillos-Carqués, \& Larrinaga-González, 2007; Llena, Moneva, \& Hernandez, 2007). With relation to the analysis of the disclosure of risk-related information in Spain, we can point to research of a general nature, developed by the Foundation for Financial Studies (FEF), included in the Annual Observatory of Good Company Management, which academics and professionals from the private sector have taken part in.

The majority of the studies on risk disclosure that have been carried out use the content analysis technique of annual and management reports (Beretta \& Bozzolan, 2004; Lajili \& Zéghal, 2005; Mohobbot, 2005; Linsley \& Shrives, 2006; Abraham \& Cox, 2007; Abraham \& Shrives, 2014; Ali \& Taylor, 2014; Rodríguez Domínguez \& Noguera Gámez, 2014), with the exception of the study by Solomon et al. (2000) which uses a postal survey as the research method. The first empirical studies on risk disclosure mark a clear trend towards the use of variables such as size, sector, benefits, risk level, as well as towards confirmation of hypotheses related to this type of information (quantitative, narrative, positive, negative, neutral, or historical or prospective); whilst in more recent studies analysis of the relationship between risk disclosure and the characteristics of the corporate governance of the company, such as the ownership structure, the number of executive directors on the board, the structure of the board (number of independent members) and listing on international stock markets, stand out.

With respect to the results obtained from these empirical studies, it may be concluded that, in general, in the majority of the cases these are consistent. Hence, all the analysed studies are in agreement that risk information disclosed by the companies is predominantly narrative and positive, and find no significant association between the company profitability and risk disclosure. Despite this apparent consistency, the existence of contradictory results can also be observed. Thus, for example, whilst Beretta and Bozzolan (2004), Lajili and Zéghal (2005) and Rodríguez Domínguez and Noguera Gámez (2014) found no link between the company size and risk disclosure, Mohobbot (2005), Linsley and Shrives (2006), Linsley et al. (2006) and Cabedo Semper and Tirado Beltrán (2009) note that there is a positive relationship between this variable and the risk 
disclosure index. On the other hand, whilst the majority of the studies found that no association between level of risk and risk disclosure (Lajili \& Zéghal, 2005; Mohobbot, 2005; Linsley et al., 2006; Cabedo Semper \& Tirado Beltrán, 2009; Rodríguez Domínguez amd Noguera Gámez, 2014), Linsley and Shrives (2006) found a positive association in two of the seven indicators used to measure risk level. In addition, these authors found meaningful evidence of prospective risk information, contrary to the majority of the studies that indicate information disclosure based on the company's past events (Beretta \& Bozzolan, 2004; Lajili \& Zéghal, 2005; Mohobbot, 2005; Linsley et al., 2006).

\section{Hypotheses}

A first set of hypotheses relates to some organizational characteristics which may influence both the amount and quality of information voluntarily disclosed by companies. Such factors are usually treated as control variables.

Size: the underlying assumption is that large firms are more visible than smaller ones and, therefore, the former are more likely to be scrutinized by stakeholders than small companies. Moreover, the number of stakeholders increases when company size becomes bigger (Dobler et al., 2011). Hence, according to the stakeholder theory, larger firms will face greater stakeholders' pressures to disclose information and, consequently, they are more likely to disclose voluntary information than smaller ones.

According to Amran, Bin, \& Hassan (2009), the bigger a company, the higher the number of stakeholders interested in its risk position. Therefore, from the stakeholder theory standpoint, the tendency towards the disclosure of risk information will be higher in larger companies compared to smaller firms. Nevertheless, empirical evidence regarding the influence of company size on the extent of risk disclosures is contradictory. Beretta and Bozzolan (2004) and Lajili and Zéghal (2005) found that firm size may not be a critical determining factor in corporate risk reporting, while other studies observed a positive relationship between firm size and the level of risk disclosures (Mohobbot, 2005; Linsley \& Shrives, 2006; Amran et al., 2009; Dobler et al., 2011). Despite these mixed results, a positive relation is expected between firm size and the level of risk disclosures.

$\mathbf{H}_{1}$. There is a positive association between firm size and the extent of risk disclosures.

Profitability: Profitability can be seen as a sign of good management. Therefore, profitable firms will be willing to disclose more corporate information as a means of legitimizing their management skills and obtaining stakeholders' approval. As regards risk disclosure, Linsley and Shrives (2006) posit that those firms that carry out an effective risk management will obtain higher benefits which, in turn, will result in a higher level of risk disclosures as a way of showing their management competence to stakeholders.

These arguments suggest that firms in good financial conditions are likely to disclose more risk information than companies whose level of profitability is lower. However, the empirical research on this subject did not find evidence of the existence of a significant association between a company's profitability and its risk disclosure level (Mohobbot, 2005; Linsley \& Shrives, 2006; Rodríguez Domínguez y Noguera Gámez, 2014). Despite the prior studies' findings, a hypothesis concerning the influence of a firm's profitability on the extent to which it discloses risk information is put forward as follows:

$\mathbf{H}_{2}$. There is a relationship between a company's profitability and the extent of risk disclosure. 
The second set of hypotheses is concerned with other firm-specific factors that could affect both the level and quality of voluntary disclosures made by companies.

Industry membership: the industry's nature can affect the extent to which companies belonging to such an industry are subjected to specific reporting requirements. Moreover, companies belonging to some industries are usually exposed to greater attention from stakeholders in relation to their performance and, consequently, face greater pressures to disclose more information.

Empirical research on the relationship between industry and the extent of risk disclosures has reached indecisive results. On the one hand, Beretta and Bozzolan (2004), Abraham and Cox (2007) and Rodríguez Domínguez and Noguera Gámez (2014) reported that a significant association between such variables does not exist. On the other hand, Amran et al., (2009) demonstrated the existence of a relationship between the nature of the industry and the extent of risk disclosure.

This study's sample includes firms belonging to the banking sector which are subjected to stricter risk reporting legislation. As regulations guide the reporting behaviour of organizations by imposing the procedures to be applied or the items to be included, it is expected that those firms belonging to the banking sector will disclose more risk information than the remaining companies in the sample (Linsley et al., 2006; Amran et al., 2009). Furthermore, due to the complexity of their activities, financial firms are exposed to greater attention from stakeholders in relation to their business practices. Accordingly, they have more incentives to disclose risk information in order to satisfy their stakeholders' demands. These arguments suggest that there may be a relationship between the disclosure level of risk information and the industry in which a firm operates.

H3. There is a relationship between the extent of risk disclosures and the nature of the industry in which a firm operates.

Ownership structure: Ownership structure has an influence on risk disclosure (ICAEW, 1997). If a firm is controlled by few shareholders, it is more likely that risk information will be disclosed in private, i.e. during the board meetings. In contrast, if the number of minority or foreign shareholders is high, the shareholders who do not belong to the board would exert a greater pressure over the management in order to disclose more risk information (Mohobbot, 2005).

Despite some studies having shown that firms whose ownership structure involves various stakeholder groups tend to disclose more corporate information than those firms whose shareholding structure is limited (Jaggi \& Low, 2000), there is no evidence of a significant relationship between a firm's ownership structure and its risk disclosure practices (Mohobbot, 2005). Hence, the following hypothesis has been established:

$\mathbf{H}_{4}$. There is a possible association between a firm's ownership structure and the extent of risk disclosure.

Presence of independent Board members: Corporate governance variables play a key role in developing companies' reporting practices, since voluntary corporate disclosures depend on how management perceives the importance of stakeholders' information needs and responds to them (Oliver, 1991). The underlying assumption is that independent directors tend to be more sensitive to stakeholders' information requests (Abraham \& Cox, 2007; Garcia-Sanchez, Rodriguez-Dominguez, \& Gallego-Alvarez, 2011).

Most previous studies reported that there is a positive relationship between the number of independent board members and the extent of voluntary corporate disclosure (Gul \& Leung, 2004; Leung \& Horwitz, 2004). However, results obtained by Eng and Mak (2003) suggest a negative relationship, whereas Garcia-Sanchez et al. (2011) and Rodríguez Domínguez and Noguera Gámez (2014) found a no statistically significant association. With regard to risk reporting, 
Abraham and Cox (2007) found that the number of executive directors and independent directors are determinants of the extent of risk disclosure. Therefore, the fifth hypothesis is stated:

H5. There is a positive association between the number of independent directors of the Board and the extent of risk disclosure.

The last set of hypotheses is concerned with several factors that could be particularly associated with the volume and quality of risk information disclosure.

Level of risk: firms with higher level of risk have an incentive to disclose more risk information in order to justify their situation and explain how they manage their risks. Moreover, when the firm level of risk is high it receives greater attention from its stakeholders in relation to its activities and, therefore, it faces greater pressures to disclose more information (Kanto \& Schadewitz, 1997).

Most empirical studies report that a significant association between the level of firm risk and the extent of risk disclosure does not exist (Lajili \& Zéghal, 2005; Mohobbot, 2005; Linsley et al., 2006; Amran et al., 2009; Miihkinen, 2012; Rodríguez Domínguez \& Noguera Gámez, 2014), although Linsley and Shrives (2006) and Dobler et al. (2011) demonstrated the existence of a positive relationship between the level of risk disclosure and some proxies for firm risk. The related hypothesis is stated as follows:

$\mathbf{H}_{6}$. There is a significant association between the risk level of a firm and the extent of risk disclosure.

Quotation on foreign stock markets: Several arguments support the existence of a relationship between the level of risk disclosures made by a firm and the fact that such a firm is listed on a foreign stock market. Firstly, the extent and characteristics of risk disclosure are linked to risk reporting regulations and the institutional setting in which a firm operates (Dobler et al., 2011). Secondly, as a result of the competition for obtaining capital in international markets and the increasing pressure from stakeholders, firms operating in a global context tend to disclose more information in their annual reports than those operating within a local context (Gul \& Leung, 2004).

Marshall \& Weetman (2002) and Abraham y Cox (2007) examined the amount of financial risk information disclosed in the UK annual reports by UK firms with a US dual listing and found that it was higher than the level of risk disclosure of those companies which were not listed on the US stock market. In order to test whether this result is also verified in the case of Spanish companies, the following hypothesis was stated:

H7. There is a positive association between the quotation on foreign stock markets and the extent of risk disclosure.

Tracking of the COSO Report: The COSO I and the COSO II reports represent a standard framework in the field of internal control and risk management, emphasizing risk disclosure rather than focusing on specific measurement techniques (Power, 2007). Therefore, it can be expected that companies that follow the COSO methodology will disclose more risk information than those which do not. Similarly, previous studies found that risk disclosure practices are influenced by the existence of reporting guidelines (Abraham \& Cox, 2007; Dobler et al., 2011). Based on these premises, the last hypothesis is stated:

H8. There is a positive association between the tracking of the COSO Reports and the extent of risk disclosure. 


\section{Research design}

\section{Sample selection}

This study is focused on the firms quoted in the IBEX-35 index during the first semester of 2008. The IBEX-35 is a stock market index composed of the thirty five most liquid Spanish stocks traded in the continuous market. The IBEX-35 index was chosen because it is used as a reference for the Spanish stock market (both at national and at international level). Additionally, all the Spanish companies listed on the New York Stock Exchange (NYSE) belong to the IBEX-35 index.

The financial sector was included within the sample owing to financial firms represent $28.6 \%$ of the IBEX-35 firms. The companies that make up the sample were classified according to the industry classification adopted by Bolsas y Mercados Españoles.

\section{Methodology}

This study is focused on the annual corporate governance reports published on the sample companies' web site. Specifically, the analysis is focused on section D that firms must disclose as a part of such reports.

The year 2009 was chosen for several reasons. Firstly, it was preceded by the issuance of relevant codes and laws regarding corporate governance, internal control and risk reporting both in other countries and in Spain, such as the Olivencia Report (1998), the Aldama Report (2003), and the Law of Transparency (2003), as well as legislation from other countries such as the Sarbanes-Oxley Law and the Winter Report (both from 2002). In addition, in 2004 the COSO II Report was published related to risk management. Furthermore, the year 2006 marks an important milestone in Spain with respect to corporate governance with the issuance of the Unified Good Governance Code, which assumes the updating of the existing Olivencia and Aldama Codes, as well as the incorporation and adaptation of the recommendations of International Bodies, in particular from the European Union and some aspects of the American Sarbanes-Oxley Law (Instituto de Auditores Internos de España, 2006, p5).

In Spain's case, little empirical evidence exists concerning the disclosure of information related to internal control and risk reporting, that which stands out being the research carried out by the Foundation for Financial Studies (FEF) within the framework of the Annual Observatory for Good Corporate Governance. Professionals from both the academic and corporate worlds have carried out these studies.

Data was sourced from the Annual Reports and Annual Corporate Governance Reports, published by the companies on their own web sites and from information registered at the National Stock Market Commission and the Madrid Stock Market. In addition, during the development of the study corresponding to the years immediately before the economic crisis of 2008, FEF established the variables of the Annual Observatory for Good Corporate Governance as the basis for the analysis of information disclosed. For each variable, aggregate measures and descriptive statistics were estimated and for three categories (Board of Directors, Rights and Duties of Stakeholders and Transparency) an unweighted global index was created and another weighted index for the market capitalization of the sample companies.

In 2007, FEF acknowledged that considerable progress had been made in the standardization of corporate governance in the companies listed on the Spanish stock exchange, using the introduction of the 2006 Unified Code as a reference. Nevertheless, according to the Foundation, 
it was not until 2008 that the transitory situation disappeared and the companies were able to choose between the alternative of accepting the recommendations of the new Code or explaining satisfactorily the adoption of other criteria (FEF, 2007, p. 12). Hence, the decision was made to analyse the year 2009, with the expectation that this would allow for a preliminary evaluation of the impact of this code on the disclosure of information related to internal control and risk reporting by Spanish companies quoted in the IBEX-35 index based on the codes and laws already in force, and taking into consideration the fading of the transitory nature of the Unified Code.

Secondly, from this year, a remarkable deterioration of the Spanish economy took place, causing stakeholders to show a greater interest in firms' risk information. The severe economic and financial crisis experienced by the business sector from 2008 onwards, in conjunction with the decision made to ignore the majority of the information requests from the stakeholders, has created a gap in expectations and a lack of confidence in the business practices of organisations, and in particular, in their directors, with negative consequences both for the organizations, which reflect an unethical and exploitative image, and the economy in general. In the second quarter of 2008 in particular, Spain suffered an economic decline that continued until 2009. However it was not until the year 2010 when the global financial crisis triggered a crisis in the euro monetary system, forcing the country to take austerity measures due to the potential need to be rescued by the Eurozone. As well as austerity measures, 2010 is distinguished by an increase in taxes, the unfolding of black week in Spain with important losses on the Madrid Stock Exchange, general strikes by different unions, a cut in public spending as well as the fall of IBEX-35. Hence, in line with the study by Ali and Taylor (2014) and Rodríguez Domínguez and Noguera Gámez (2014), the year 2009 was chosen, given that this year follows an important period of decline and volatility that could cause companies trading on the stock exchange to recognize the importance of disclosing information related to external risk.

Content analysis was the research methodology used to measure the extent of risk disclosure. As risk information is fundamentally narrative, its quality depends on both the amount of information disclosed and the breadth of its content (Beretta \& Bozzolan, 2004). Therefore, the approach adopted in this study considers not only the quantity of risk information disclosed by sample companies, but also the kind and scope of that information.

\section{Variables}

\section{Dependent variable: risk disclosure index}

A Risk Disclosure Index was developed to measure the quantity and the quality of the risk information disclosed by the sample firms. The starting point for the construction of this index was the development of a checklist drawn from the eight components of the Enterprise Risk Management - Integrated Framework (COSO II Report). This choice is justified, firstly, because it constitutes the widest conceptual framework of risk management available and, secondly, because all the requirements established in the Spanish Unified Code of Good Governance are included in the COSO II Report.

Subsequently, each component was divided into several variables related to what each firm is supposed to disclose about risk information. Also, additional variables were included, which were specifically related to a prospective vision of risk management. As a result, a checklist was obtained consisting of twenty three items related to risk disclosure (Table 1).

This checklist was used as a basis to perform the content analysis of the annual corporate reports. The nature and scope of the information disclosed on each item were assessed according to the weighted index developed by Van Staden and Hooks (2007). This index is based on a five 
points scale [0 - not disclosed; 1 - minimum coverage, that is, anecdotal or briefly mentioned; 2 - descriptive; 3 - quantitative (defined in monetary terms or physical quantities); 4 - complete or exhaustive]. Thus, each corporate governance report was assessed and coded by applying the following scoring system: the items received a value ranging from 0 (not disclosed information about the item) to 4 (complete or exhaustive information about the item).

From this analysis a weighted index, called Risk Disclosure Index (RDI), was calculated as follows:

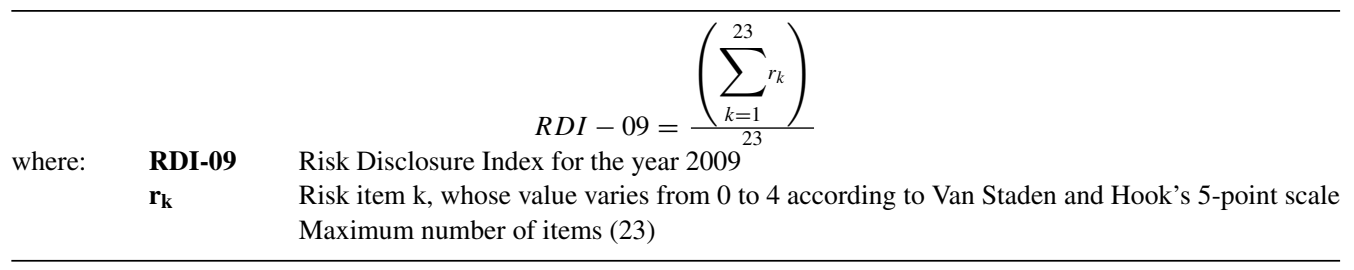

\section{Independent variables}

Organizational size: due to the high values attributed to this measure, the natural logarithm of the total assets from the annual report of 2009 was used to compute the value of the SIZE variable.

Profitability: corporate profitability (PROFIT) was measured by the return on invested capital (ROIC) in 2009, which compares the net operating profit to the invested capital, including longterm debt and common and preferred shares. According to Theodorou and Florou (2008), the ROIC is a "criterion of performance in order to incorporate the effect of cost, revenues and profits" (p. 107) and an "important indicator for the long term growth of the firm and for competitive advantage" (p. 115). The ROIC is considered because it measures the return on all capital invested in an asset, rather than just focusing on the equity component of the investment (Damodaran, 2007).

Industry membership: the SECTOR variable is defined as a dummy variable which receives the value of one if the analyzed company belongs to the financial sector and the value of zero if the firm belongs to the remaining industries. There are a greater number of regulations related to the banking sector (for example, the Basel Accords proposed by the Basel Committee on Banking Supervision) that encourage the disclosure of risk information to support market discipline requirements (Linsley et al., 2006). Therefore, "as the banking sector has been at the forefront of developments in risk management and risk measurement techniques then we would expect banks to be disclosing a range of important types of risk information" (Linsley et al., 2006, p. 272). Moreover, according to Borio and Tsatsaronis (2006), due to the higher degree of leverage, the greater oversight by regulators and the trading operations, it is considered that risks are most relevant in the financial sector. The authors observed that even though during the eighties companies began to disclose quantitative risk information, this development has been limited to financial organizations, for whom the issue of risk is more important as a result of the high level of leverage that these typically manage.

Furthermore, as a result of the global financial crisis that have shown that "bank failures can create large contingent liabilities for the government" (Arslanalp \& Liao, 2014, p. 316), the survey conducted by Ernst and Young (2011) reveals that the most important business risks are concentrated in the areas of regulation and compliance. The survey shows that the asset management, banking and real estate sectors concentrate the highest impact of the three major global risks (regulatory and compliance, access to credit and slow recovery). As risks are more 
Table 1

Risk disclosure items.

\section{Internal environment}

Risk management philosophy

Risk culture

Board of Direc tors

Integrity and ethical values

Commitment with competences

Organizational structure

Authority and responsibility assignment

Human Resources Policies

2. Objective setting

Strategic \& operational information and compliance objectives

Accepted risk

Risk tolerance

\section{Events identification}

External and internal events, influencing factors

Events identification techniques

Distinction between risks and opportunities

4. Risk assessment

Probability and impact setting

Risk classification

Risk assessment techniques

5. Risk response

Probable risk responses assessment

Costs and benefits assessment

6. Control activities

Types of control activities

Policies and procedures

7. Information and communication

Information and communication

8. Monitoring

Monitoring activities

relevant for the financial sector, this sector was classified as the riskiest compared to the remaining five sectors.

Ownership structure: the STRUC variable was calculated dividing the number of shares which have the right to vote belonging to the members of the Board into the total number of shares.

Presence of independent Board members: the BOARD variable was calculated as the ratio of the number of non-executive members and the total number of Board members.

Level of risk: the firms' level risk (RISK) was measured by beta coefficient (average from the year 2009). According to Linsley and Shrives (2006), level of risk can be measured in different ways: gearing ratio, asset cover, beta factor, ratio of book value of equity to market value of equity, quiscore and Business in the Community Index of Corporate Environmental Engagement (BiE Index). In order to consider both corporate and market risk, in this research the beta coefficient was selected as a measure of risk.

Quotation on foreign stock markets: the COT variable is defined as a dummy variable assuming 1 if the firm is listed on international stock markets and 0 to the contrary. 
Tracking of the COSO Report: the COSO variable is defined as a dummy variable assuming 1 if the firm follows the COSO report and 0 to the contrary. To measure this variable it was analyzed whether a firm indicates in its corporate governance reports that it follows the guidelines of the COSO Report.

The information for measuring the BOARD and STRUC variables was found in sections B.1.3 and A.3 of corporate governance reports, respectively. Data for the PROFIT and RISK variables were obtained from the 2009 annual reports.

In order to identify what factors have a significant influence on the Spanish companies' risk disclosure, a multivariate analysis was carried out through the following regression model:

$$
\text { RDI- } 09=\mathrm{b}_{0}+\mathrm{b}_{1} \text { SECTOR }+\mathrm{b}_{2} \text { SIZE }+\mathrm{b}_{3} \text { COSO }+\mathrm{b}_{4} \mathrm{COT}+\mathrm{b}_{5} \text { BOARD }+\mathrm{b}_{6} \mathrm{STRUC}+\mathrm{b}_{7} \mathrm{PROFIT}+\mathrm{b}_{8} \mathrm{RISK}+\varepsilon_{i}
$$

\section{Results: analysis and discussion}

\section{Determining Factors of Risk Disclosure}

The Spearman correlation analysis was performed to test the existence of correlation between the dependent variable (RDI-09) and the independent variables. At a first stage, the analysis was carried out considering all the sample firms (35). The results of the first stage are shown in Table 2.

As can be seen in Table 2, the variables SECTOR, SIZE and RISK show the highest correlation index regarding the dependent variable RDI-09 $(0.473 ; 0.429$ and 0.451 , respectively) and a statistically significant value $(\mathrm{p}<0.05)$, while the remaining variables show a lower significant value $(\mathrm{p}>0.05)$ as well as a low correlation index (their Spearman correlations are equal or less than 0.35). Therefore, the results indicate that there is no significant association between the variables COSO, COT, BOARD, STRUC, and PROFIT and the RDI-09.

The positive and significant value of the SIZE variable indicates that there is a positive relationship between firm size and the RDI-09. Accordingly, hypothesis $\mathrm{H}_{1}$ can be confirmed. This result is consistent with the stakeholder theory postulates as well as with most previous studies' findings (Mohobbot, 2005; Linsley \& Shrives, 2006; Linsley et al., 2006) which also found that firm size is positive and significantly related to the level of risk information disclosed.

The results in Table 2 indicate that risk disclosure is significantly related to the activity sector to which a firm belongs. Thus, in contrast to other previous studies (Beretta \& Bozzolan, 2004; Abraham \& Cox, 2007; Rodríguez Domínguez \& Noguera Gámez, 2014), the findings entail that industry membership does have an influence on the level of risk disclosure which provides support to hypothesis $\mathrm{H}_{3}$. However, this result must be carefully valued since the majority of the studies related to risk disclosure eliminate the companies belonging to the financial sector, whereas such firms have been included in this study's sample, which might have influenced the results. Therefore, it will be necessary to try to confirm if these differences are or are not significant.

Empirical evidence indicates that, as stated in hypothesis $\mathrm{H}_{6}$, there is a positive relationship between the RDI-09 and the firm's level of risk (RISK), which means that the sample firms that disclose more risk information are those with a higher level of risk. This result corroborates the stakeholder theory arguments as it suggests that demands for risk-related information from influential stakeholders, such as investors and creditors, have a significant influence on the level of risk information disclosed by riskier firms. However, again this result might be a consequence of the fact that the sample in this study includes firms belonging to the financial and real state sector. Such firms not only have a higher leverage and a higher level of risk but they are also 
Table 2

Spearman correlation matrix.

\begin{tabular}{|c|c|c|c|c|c|c|c|c|c|}
\hline & RDI-09 & SECTOR & SIZE & COSO & COT & BOARD & STRUC & PROFIT & RISK \\
\hline RDI-09 & 1.000 & $\begin{array}{l}0.473^{* *} \\
(0.006)\end{array}$ & $\begin{array}{l}0.429^{*} \\
(0.014)\end{array}$ & $\begin{array}{l}-0.285 \\
(0.113)\end{array}$ & $\begin{array}{l}0.084 \\
(0.648)\end{array}$ & $\begin{array}{l}-0.318 \\
(0.076)\end{array}$ & $\begin{array}{l}0.135 \\
(0.461)\end{array}$ & $\begin{array}{l}-0.219 \\
(0.245)\end{array}$ & $\begin{array}{l}0.451^{\text {*** }} \\
(.010)\end{array}$ \\
\hline SECTOR & & 1.000 & $\begin{array}{l}0.234 \\
(0.198)\end{array}$ & $\begin{array}{l}-0.426^{*} \\
(0.015)\end{array}$ & $\begin{array}{l}0.096 \\
(0.601)\end{array}$ & $\begin{array}{l}-0.253 \\
(0.162)\end{array}$ & $\begin{array}{l}-0.049 \\
(0.790)\end{array}$ & $\begin{array}{l}-0.108 \\
(0.571)\end{array}$ & $\begin{array}{l}0.239 \\
(0.188)\end{array}$ \\
\hline SIZE & & & 1.000 & $\begin{array}{l}-0.110 \\
(0.547)\end{array}$ & $\begin{array}{l}0.536^{* *} \\
(0.002)\end{array}$ & $\begin{array}{l}-0.114 \\
(0.534)\end{array}$ & $\begin{array}{l}-0.028 \\
(0.880)\end{array}$ & $\begin{array}{l}-0.241 \\
(0.200)\end{array}$ & $\begin{array}{l}0.550^{\text {*** }} \\
(0.001)\end{array}$ \\
\hline COSO & & & & 1.000 & $\begin{array}{l}0.051 \\
(0.782)\end{array}$ & $\begin{array}{l}0.286 \\
(0.113)\end{array}$ & $\begin{array}{l}-0.171 \\
(0.349)\end{array}$ & $\begin{array}{l}0.392^{*} \\
(0.032)\end{array}$ & $\begin{array}{l}-0.043 \\
(0.816)\end{array}$ \\
\hline COT & & & & & 1.000 & $\begin{array}{l}-0.191 \\
(0.294)\end{array}$ & $\begin{array}{l}-0.312 \\
(0.082)\end{array}$ & $\begin{array}{l}0.119 \\
(0.532)\end{array}$ & $\begin{array}{l}0.205 \\
(0.260)\end{array}$ \\
\hline BOARD & & & & & & 1.000 & $\begin{array}{l}-0.147 \\
(0.421)\end{array}$ & $\begin{array}{l}-0.097 \\
(0.609)\end{array}$ & $\begin{array}{l}-0.384^{*} \\
(0.030)\end{array}$ \\
\hline STRUC & & & & & & & & $\begin{array}{l}-0.140 \\
(0.460)\end{array}$ & $\begin{array}{l}0.128 \\
(0.485)\end{array}$ \\
\hline PROFIT & & & & & & & & 1.000 & $\begin{array}{l}-0.414^{*} \\
(0.023)\end{array}$ \\
\hline RISK & & & & & & & & & 1.000 \\
\hline
\end{tabular}

* The correlation is significant at the 0.05 level (2-tailed)

** The correlation is significant at the 0.01 level (2-tailed) 
Table 3

Summary of hypotheses.

\begin{tabular}{|c|c|c|}
\hline No. & Hypotheses & Accept / Reject \\
\hline $\mathrm{H}_{1}$ & $\begin{array}{l}\text { There is a positive association between firm size and the extent of risk } \\
\text { disclosures. }\end{array}$ & Accept \\
\hline $\mathrm{H}_{2}$ & $\begin{array}{l}\text { There is a relationship between a company's profitability and the extent of } \\
\text { risk disclosure. }\end{array}$ & Reject \\
\hline $\mathrm{H}_{3}$ & $\begin{array}{l}\text { There is a relationship between the extent of risk disclosures and the nature } \\
\text { of the industry in which a firm operates. }\end{array}$ & Accept \\
\hline $\mathrm{H}_{4}$ & $\begin{array}{l}\text { There is a possible association between a firm's ownership structure and } \\
\text { the extent of risk disclosure. }\end{array}$ & Reject \\
\hline $\mathrm{H}_{5}$ & $\begin{array}{l}\text { There is a positive association between the number of independent } \\
\text { directors of the Board and the extent of risk disclosure. }\end{array}$ & Reject \\
\hline $\mathrm{H}_{6}$ & $\begin{array}{l}\text { There is a significant association between the risk level of a firm and the } \\
\text { extent of risk disclosure. }\end{array}$ & Accept \\
\hline $\mathrm{H}_{7}$ & $\begin{array}{l}\text { There is a positive association between the quotation on foreign stock } \\
\text { markets and the extent of risk disclosure. }\end{array}$ & Reject \\
\hline $\mathrm{H}_{8}$ & $\begin{array}{l}\text { There is a positive association between the tracking of the COSO Reports } \\
\text { and the extent of risk disclosure. }\end{array}$ & Reject \\
\hline
\end{tabular}

Table 4

Summary of the regression model by the Stepwise regression.

\begin{tabular}{lllll}
\hline Model & $\mathrm{R}$ & R-squared & Corrected R squared & Error \\
\hline $1^{\mathrm{a}}$ & 0.624 & 0.389 & 0.369 & 0.36409 \\
$2^{\mathrm{b}}$ & 0.687 & 0.472 & 0.436 & 0.34428 \\
\hline
\end{tabular}

a Predictable variables: (Constant), RISK.

b Predictable variables: (Constant), RISK, SIZE.

subjected to stringent risk reporting requirements which may also have an influence on their level of risk disclosures.

Finally, no statistically significant relation was found between the remaining independent variables (PROFIT, STRUC, BOARD, NYSE and COSO) and the RDI-09. These factors appear to have no impact on the level of risk information disclosed by the sample firms. Therefore, despite the consistency of the previously presented arguments, hypotheses $\mathrm{H}_{2}, \mathrm{H}_{4}, \mathrm{H}_{5}, \mathrm{H}_{7}$ and $\mathrm{H}_{8}$ are rejected (Table 3).

At a second stage, the Stepwise method was used to estimate the regression model and to determine which of the explanatory variables better explain the dependent variable (RDI-09). According to the Stepwise method the first explanatory variable to be introduced into the regression model is the RISK variable and the next (and the last) explanatory variable to be introduced into the regression model is SIZE. Both variables provide a statistically significant explanation of the dependent variable. A significant relationship with the Risk Disclosure Index's value was only noted for two out of the eight independent variables considered in the regression model. The addition of the remaining variables does not improve the explanatory power of the model. Table 4 summarizes the results of the regression analysis.

As shown in Table 4, the value of the coefficient $\mathrm{R}$ indicates that both independent variables (RISK and SIZE) explain the dependent variable and that their correlation is high. Nonetheless, the correlation of the second model is higher than the first one, i.e., the second model (the one that considers the two explanatory variables) improves the first model (the one that only considers an 
Table 5

Results of the regression analysis.

\begin{tabular}{|c|c|c|c|c|c|c|}
\hline \multicolumn{2}{|c|}{ Model } & \multicolumn{2}{|c|}{ Non- standardized coefficients } & \multirow{2}{*}{$\begin{array}{l}\text { Standardized Coefficient } \\
\text { Beta }\end{array}$} & \multirow[t]{2}{*}{$\mathrm{t}$} & \multirow[t]{2}{*}{ Sig. } \\
\hline & & B & Typical error & & & \\
\hline \multirow[t]{2}{*}{1} & Constant & 0.727 & 0.224 & & 3.243 & 0.003 \\
\hline & RISK & 1.067 & 0.244 & 0.624 & 4.374 & 0.000 \\
\hline \multirow[t]{3}{*}{2} & Constant & 0.990 & 0.245 & & 4.037 & 0.006 \\
\hline & RISK & 0.690 & 0.291 & 0.404 & 2.375 & 0.024 \\
\hline & SIZE & $8.295 \mathrm{E}-7$ & 0.000 & 0.362 & 2.133 & 0.041 \\
\hline
\end{tabular}

explanatory variable). More specifically, the variance analysis shows significant levels lower than 0.05 in both models, while the condition indices are not relatively high (condition index for both models $=6.513$, lower than the limit of 20 stated by Belsey).

Except for the SECTOR variable, these results are consistent with the Spearman correlations presented in Table 2, which indicated that such variables (RISK and SIZE) would be potential explanatory variables in the model, as they showed high correlation values. It is important to note that, unlike the Spearman correlation, the stepwise regression considers a simultaneous effect of the variables. The regression results are presented in Table 5. According to the findings displayed in Table 5, the estimated final model corresponds to model 2 which includes both firm size and the risk level as the explanatory variables of the Risk Disclosure Index's value. Thus, the model can be expressed as follows:

$$
\text { RDI-09 }=0.990+0.690 \text { RISK+8.295E-7 SIZE }
$$

The regression results show a significant positive association (at the 0.05 level) between the RDI and both the RISK and SIZE variables, suggesting that the level of risk disclosure is higher both for riskier companies and big firms. In order to compare and ease the interpretation of the model, the standardized coefficient beta is used. Therefore, the final model is expressed as follows:RDI-09 $=0.404$ RISK+0.362 SIZE

In order to confirm whether the composition of the sample influenced the findings, at a subsequent stage, the data base was divided into two sets: the first one included the ten firms belonging to the financial sector and the second group included the twenty five remaining companies. The Spearman correlations analysis was again performed. Results indicate that, while within the financial sector the SIZE and the RISK show a statistically significant value $(\mathrm{p}<0.05)$, in the remaining sectors there is not sufficient evidence to conclude that these variables have a statistically significant relationship with the level of risk disclosure. This result confirms the contention that the inclusion in the sample of firms belonging to the financial sector has had an impact on the results. Hence, further analysis will be necessary.

\section{Sector differences: financial sector versus remaining sectors}

According to the above, the financial and real state sector is the sector that discloses more risk information. This finding could be explained by the fact that, due to their high leverage and their high exposure to risks, firms belonging to the financial sector are subjected to a greater supervision and they must comply with additional and stricter risk disclosure requirements. As a result, they tend to disclose more risk information than firms belonging to other sectors. 
Table 6

One Way ANOVA for the RDI-09 among groups.

\begin{tabular}{llrlll}
\hline & Sum of squares & df & Mean Square & F & Sig. \\
\hline Among Groups & 2.570 & 5 & 0.514 & 3.389 & 0.017 \\
Within Groups & 3.943 & 26 & 0.152 & & \\
Total & 6.513 & 31 & & & \\
\hline
\end{tabular}

* The mean difference is significant at the 0.95 level.

Table 7

Tukey post hoc test.

\begin{tabular}{lrlc}
\hline Sector & $\mathrm{N}$ & \multicolumn{2}{c}{ Subsets for alpha $=0.05$} \\
\cline { 3 - 4 } & & $1^{*}$ & $2^{*}$ \\
\hline Consumer goods & 2 & 1.3478 & 1.4106 \\
Oil and energy & 9 & 1.5217 & 2.0739 \\
Technology and telecommunications & 2 & 1.5725 & 1.000 \\
Basic materials, industry and construction & 6 & 1.5797 & \\
Services & 3 & 0.967 & \\
Financial and real state & 10 & & \\
Sig. & & & \\
\hline
\end{tabular}

* It shows the means for groups in homogeneous subsets.

Several tests were carried out in order to analyze whether there are significant differences between the mean of the sectors and the RDI-09. Firstly, a comparison of means was carried out through a T-test for independent samples. To do this, firms were grouped into two groups (dichotomous variable): the first one included the firms belonging to the financial sector and the second group included the firms belonging to the five remaining sectors. The results indicate a mean of 2.0739 for the financial sector, a mean of 1.4822 for the remaining sectors, a difference between means of 0.59170 and a significance level of 0.003 , indicating that there is a significant difference between the financial sector's mean and the remaining sectors' mean $(\mathrm{p}<0.05)$.

To confirm these results, a comparison between each sector and the financial and property sector was carried out (multitomous variable). Thus, an analysis of variance (ANOVA) was performed with a confidence level of $95 \%$. The homogeneity test of the variances indicates a value significantly lower than 0.05 (0.017), hence it can be asserted that the differences of means between the sectors are statistically significant (Table 6).

The Tukey test was applied in order to compare the means of each sector with the others. Those sectors which did not differ significantly were grouped in columns. The results show a significant difference of means at the level of $95 \%$ between the financial sector and the remaining sectors. The greatest difference of means with a significance level lower than $0.05(0.011)$ is found between the oil and energy sector and the financial and real state sector.

Finally, Table 7 shows that the five top sectors (Consumer goods, Oil and energy, Technology and telecommunications, Basic materials, industry and construction and Services) are homogeneous, showing a significance level of 0.967 . This indicates that there is not sufficient evidence to conclude that the differences between this set of five sectors are significant, while the financial and real state sector constitutes a different group. Therefore, the hypothesis that the firms belonging to the financial sector have a higher RDI than the remaining ones can be confirmed. Nonetheless, this result should be taken carefully, since it is important to note that even though most studies 
related to the disclosure of risk information have differentiate the financial sector, due to its special treatment in matters of risk (Beretta \& Bozzolan, 2004; Mohobbot, 2005; Linsley \& Shrives, 2006; Cabedo Semper \& Tirado Beltrán, 2009), this study have included this sector in the sample, which has certainly influenced the results.

\section{Conclusions}

As noted by Solomon et al. (2000) corporate governance codes have recognized the need to improve corporate risk disclosure and provide guidance for such disclosures. Understanding the drivers for firms to disclose risk-related information may assist regulators and standards setters in promoting both the spread and the improvement of such disclosures through the issuance of corporate governance codes and reporting guidelines (Abraham \& Cox, 2007; Dobler et al., 2011). This study responds to recent calls for more research on this subject.

From the analysis, three factors, namely firm size, industry membership and level of risk, were found to explain sample firms' risk disclosure practices as they are positively and statistically related to the value of the RDI-09. As regards the remaining factors, no statistically significant relation was found between them and the value of RDI-09. These factors appear to have no impact on the level of risk information disclosed by the sample firms. As a result, only three out the eight hypotheses were confirmed. However, to some extent, these results may be attributed to the sample's composition. Specifically, the inclusion of firms belonging to the financial sector has had an impact on the results.

Like all empirical studies, there are a number of limitations which should be taken into consideration in interpreting this study's findings and conclusions. With regard to the sample, it was limited to only the thirty-five firms quoted in the IBEX-35 index which may interfere with generalizing results to smaller firms. Moreover, even though an attempt was made to analyze the differences between the financial sector and the remaining sectors, the fact that financial firms have been included in the sample has impacted upon results. With regard to the period under analysis, data corresponding to only one year are insufficient to obtain definite conclusions about the impact of the analyzed variables on their risk reporting practices.

Despite the aforementioned limitations, this paper contributes to the international literature in a number of ways. Little evidence is available relating to Spanish firms' risk reporting practices and, therefore, the knowledge of such practices is relatively low. This study was intended to extend the scope of the current understanding of risk reporting practices and their determinants by examining some factors that may have an influence on risk information disclosed by Spanish firms. Although, it was focused on the Spanish situation, the results and discussions concerning risk reporting practices' determinants in Spanish firms could be interesting in other countries as well. They could be especially useful for regulators and policy-makers in order to enhance risk disclosure and to improve transparency.

\section{References}

Abraham, S., \& Cox, P. (2007). Analyzing the determinants of narrative risk information in UK FTSE 100 annual reports. The British Accounting Review, 39(3), 227-248.

Abraham, S., \& Shrives, P. J. (2014). Improving the relevance of risk factor disclosure in corporate annual reports. The British Accounting Review, 46, 91-107.

Ahmed, A. S., Beatty, A., \& Bettinghaus, B. (2004). Evidence on the efficacy of interest-rate risk disclosures by commercial banks. The International Journal of Accounting, 39(3), 223-251. 
Ahmed, K., \& Courtis, J. (1999). Associations between corporate characteristics and disclosure levels in annual reports: a meta-analysis. British Accounting Review, 31(1), 35-61.

Ali, M.M. and Taylor, D. (2014). Content analysis of corporate risk disclosure in Malaysia. 4th Annual International Conference on Accounting and Finance, Global Science \& Technology Forum: 15-24.

Amran, A., Bin, A., \& Hassan, B. (2009). Risk reporting - An exploratory study on risk management disclosure in Malaysian annual reports. Managerial Auditing Journal, 24(1), 39-57.

Aranguren-Gómez, N., \& Ochoa-Laburu, E. (2008). Divulgación de información sobre empleados y medio ambiente en España y Alemania: una nota de investigación. Revista de Contabilidad - Spanish Accounting Review, 11(2), $123-142$.

Archel Domench, P. (2003). La divulgación de la información social y medioambiental de la gran empresa española en el periodo 1994-1998: situación actual y perspectivas. Revista Española de Financiación y Contabilidad, 32(117), 571-601.

Arslanalp, S., \& Liao, Y. (2014). Banking sector contingent liabilities and sovereign risk. Jounal of Empirical Finance, 29, 316-330.

Beretta, S., \& Bozzolan, S. (2004). A framework for the analysis of firm risk communication. The International Journal of Accounting, 39(1), 265-288.

Blankley, A., Lamb, R., \& Schroeder, R. (2002). The disclosure of information on market risk: evidence from the Dow 30. Managerial Auditing Journal, 17(8), 438-451.

Boesso, G., \& Kumar, K. (2007). Drivers of corporate voluntary disclosure. A framework and emipirical evidence from Italy and the United States. Accounting, Auditing and Accountability Journal, 20(2), 269-296.

Botosan, C. A. (2004). Discussion of a framework for the analysis of firm risk communication. The International Journal of Accounting, 39(3), 289-295.

Cabedo Semper, J. D., \& Tirado Beltrán, J. M. (2009). Divulgación de información sobre riesgos: una propuesta para su medición. Innovar, 19(34), 121-134.

Callao-Gastón, S., Gasca-Galán, M. M., \& Jarne-Jarne, J. I. (2007). Gobierno corporativo y deficiencias de la información contable. Revista de Contabilidad, 10(1), 133-156.

Criado-Jiménez, I., Fernández-Chulián, M., Husillos-Carqués, F. J., \& Larrinaga-González, C. (2007). Compliance with mandatory environmental reporting in financial statements: the case of Spain (2001-2003). Journal of Business Ethics, $79(3), 245-262$.

Damodaran, A. (2007). Return on capital (ROC), return on invested capital (ROIC) and Return on Equity (ROE): Measurement and implications. Accesed April, 8, 2015 from http://people.stern.nyu.edu/adamodar/ pdfiles/papers/returnmeasures.pdf

Dobler, M. (2008). Incentives for risk reporting - A discretionary disclosure and cheap talk approach. The International Journal of Accounting, 43(2), 184-206.

Dobler, M., Lajili, K., \& Zéghal, D. (2011). Attributes of corporate risk disclosure: an international investigation in the manufacturing sector. Journal of International Accounting Research, 10(2), 1-22.

Dunne, T., Helliar, C., Power, D., Mallin, C., Ow-Yong, K., \& Moir, L. (2004). The introduction of derivatives reporting in the UK: a content analysis of FRS 13 disclosures. Journal of Derivatives Accounting, 1(2), 205-219.

Eng, L. L., \& Mak, Y. T. (2003). Corporate Governance and voluntary disclosure. Journal of Accounting and Public Policy, 22, 325-345.

Ernst \& Young (2011). Los 10 principales riesgos de negocios. Accesed April 8, 2015 from http://www.ey.com/ Publication/vwLUAssets/Los_nuevos_riesgos_en_los_negocios/\$FILE/Los_nuevos_riesgos_en_los_negocios.pdf

(2007). Fundación de Estudios Financieros (FEF). Observatorio de Gobierno Corporativo y Transparencia Informativa de las Sociedades Cotizadas en el Mercado Continuo Español, 2006. Madrid: Fundación de Estudios Financieros.

Gabillon, E., \& Gabillon, J. C. (2012). Corporate risk management and information disclosure. Finance, 33(2), 101-128.

Gallego-Álvarez, I. (2006). The use of economic, social and environmental indicators as a measure of sustainable development in Spain. Corporate Social Responsibility and Environmental Management, 13(2), 78-97.

García-Ayuso, M., \& Larrinaga, C. (2003). Environmental disclosure in Spain: Corporate characteristics and media exposure. Revista Española de Financiación y Contabilidad, 32(115), 184-214.

García-Sánchez, I. (2008). Corporate social reporting: segmentation and characterization of Spanish companies. Corporate Social Responsibility and Environmental Management, 15(4), 187-198.

Garcia-Sanchez, I. M., Rodriguez-Dominguez, L., \& Gallego-Alvarez, I. (2011). Corporate governance and strategic information on the Internet. Accounting. Auditing \& Accountability Journal, 24(4), 471-501.

Gul, F. A., \& Leung, S. (2004). Board leadership, outside directors' expertise and voluntary corporate disclosures. Journal of Accounting and Public Policy, 23(5), 351-379.

Hodder, L., Koonce, L., \& McAnally, M. L. (2001). SEC market risk disclosure: implications for judgement and decision making. Accounting Horizons, 15(1), 49-70. 
(1997). Institute of Chartered Accountants in England and Wales (ICAEW). Financial Reporting of Risk: Proposal for a Statement of Business Risk. London: The Institute of Chartered Accountants in England and Wales.

(2011). Institute of Chartered Accountants in England and Wales (ICAEW). Reporting business risks: Meeting expectations. London: The Institute of Chartered Accountants in England and Wales.

Instituto de Auditores Internos de España. (2006). Código Unificado de Buen Gobierno. Posición del Instituto de Auditores Internos de España. http://www.iai.es 1-17.

Jaggi, B., \& Low, P. Y. (2000). Impact of culture, market forces, and legal system on financial disclosures. The International Journal of Accounting, 35(4), 495-519.

Jorgensen, B. N., \& Kirschenheiter, M. T. (2003). Discretionary risk disclosures. The Accounting Review, 78(2), 449-469.

Kanto, A., \& Schadewitz, H. (1997). A multidimensional model for the disclosure policy of a firm. Scandinavian Journal of Management, 13(3), 229-249.

Lajili, K., \& Zéghal, D. (2005). A content analysis of risk management disclosures in Canadian annual reports. Canadian Journal of Administrative Sciences, 22(2), 125-142.

Larrinaga, C., Carrasco, F., Correa, C., Llena, F., \& Moneva, J. M. (2002). Accountability and accounting regulation: the case of the Spanish environmental disclosure standard. The European Accounting Review, 11(4), 723-740.

Leung, S., \& Horwitz, B. (2004). Director ownership and voluntary segment disclosure: Hong Kong evidence. Journal of International Financial Management and Accounting, 15(3), 235-260.

Linsley, P., \& Shrives, P. (2000). Risk management and reporting risk in the UK. Journal of Risk, 3(1), $115-129$.

Linsley, P. M., \& Shrives, P. J. (2006). Risk reporting: a study of risk disclosures in the annual reports of UK companies. The British Accounting Review, 38(4), 387-404.

Linsley, P. M., Shrives, P. J., \& Crumpton, M. (2006). Risk disclosure: an exploratory study of UK and Canadian banks. Journal of Banking Regulation, 7(3-4), 268-282.

Llena, F., Moneva, J. M., \& Hernandez, B. (2007). Environmental Disclosures and Compulsory Accounting Standards: The Case of Spanish Annual Reports. Business Strategy and the Environment, 16(1), 50-63.

Marshall, A., \& Weetman, P. (2002). Information asymmetry in disclosure of foreign exchange risk management: can regulation be effective? Journal of Economic and Business, 54(1), 31-53.

Miihkinen, A. (2012). What drives quality of firm risk disclosure? The impact of a national disclosure standard and reporting incentives under IFRS. The International Journal of Accounting, 47, 437-468.

Mohobbot, A. M. (2005). Corporate risk reporting practices in annual reports of Japanese companies. Journal of the Japanese Association for International Accounting Studies, 113-133.

Moneva, J. M., \& Llena, F. (2000). Environmental disclosures in the annual reports of large companies in Spain. The European Accounting Review, 9(1), 7-29.

Ochoa-Laburu, E. and Aranguren-Gómez, N. (2005). Divulgación de información social y medioambiental. Un estudio empírico de las empresas del IBEX 35. Comunicación presentada al XIII Congreso de AECA, Oviedo.

Oliver, C. (1991). Strategic Responses to Institutional Processes. The Academy of Management Review, 16(1), $145-179$.

Power, M. (2007). Organized Uncertainty. Designing a World of Risk Management. London: Oxford.

Prado-Lorenzo, J. M., Gallego-Álvarez, I., \& García-Sánchez, I. M. (2009). Stakeholder engagement and corporate social responsibility reporting: the ownership structure effect. Corporate Social Responsibility and Environmental Management, 16(2), 94-107.

Rajgopal, S. (1999). Early evidence on the informativeness of the SEC's market risk disclosure: the case of commodity price risk exposures of oil and gas producers. The Accounting Review, 74(3), 251-280.

Rodríguez Domínguez, L., \& Noguera Gámez, L. C. (2014). Corporate reporting on risks: Evidence from Spanish companies. Revista de Contabilidad - Spanish Accounting Review, http://dx.doi.org/10.1016/j.rcsar.2013.10.002.

Solomon, J. F., Solomon, A., Norton, S. D., \& Joseph, N. L. (2000). A conceptual framework for corporate risk disclosure emerging from the agenda for corporate governance reform. The British Accounting Review, 32(4), 447-478.

Theodorou, P., \& Florou, G. (2008). Manufacturing strategies and financial performance - The effect of advanced information technology: CAD/CAM systems. Omega - The International Journal of Management Science, 1, $107-121$.

Van Staden, C., \& Hooks, J. (2007). A comprehensive comparison of corporate environmental reporting and responsiveness. The British Accounting Review, 39(3), 197-210.

Woods, M., Dowd, K., \& Humphrey, C. (2008). The value of risk reporting: A critical analysis of value-at-risk disclosures in the banking sector. International Journal of Financial Services Management, 3(1), 45-64.

Woods, M. and Reber, B. (2003). A comparison of UK and German reporting practice in respect of disclosure post GAS 5. Paper presented at the 6th Financial Reporting and Business Communication Congress Cardiff Business School, Cardiff, July 3-4. 